\title{
Editorial Note.
}

Aт the January meeting of the Bath William Harvey and Bristol Branch of the British and Medical Association a kinematograph Kingsweston. film was exhibited showing the experiments which Harvey used to prove his theory of the circulation of the blood. This film was prepared by Sir Thomas Lewis and Dr. H. H. Dale for the celebrations held last year by the Royal College of Physicians to commemorate the tercentenary of the publication of William Harvey's Exercitatio anatomica de motu cordis et sanguinis in animalibus. It brought home convincingly the simplicity of the demonstrations which Harvey's great genius had conceived.

It is interesting to recall that at Kingsweston House near Bristol there is a contemporary portrait of Harvey, a replica apparently of one which hangs in the Kent and Canterbury Hospital. The picture is one of a group of family portraits placed in the great hall of Kingsweston by Edward Southwell, who died in 1755 .

Kingsweston, which is now the property of Dr. Napier Miles, was formerly the seat of the Southwell family.

Sir Robert Southwell (1642-1702) married Elizabeth Dering, grand-daughter of William Harvey's brother, Daniel : so that it was his great-grand-uncle's portrait that Edward Southwell placed in the panelling at Kingsweston. 
Sir Robert Southwell was a Privy Councillor, and had been Secretary of State for Ireland, and three times President of the Royal Society. He had studied medicine at Oxford and anatomy abroad.

The Rev. Richard Warner, in his Excursions from Bath, 1801, attributed the picture of Harvey to Sir Peter Lely. The Canterbury portrait has been attributed by Dr. F. William Cock to Cornelius Janssen.

\section{Meetings of Societies.}

\section{Bristol Medico-Chirurgical Society.}

The first meeting of the session was held at the University on Wednesday, 10th October, 1928, when Dr. W. K. Wills resigned the chair to the new President, Dr. H. L. Ormerod.

Dr. ORMERoD read his inaugural address on "Mental Deficiency," reported on page 1 of this number.

The Report presented by the Honorary Secretary, Mr. W. A. JACKMAN, showed that during the year 1927-28 eighteen new members had been elected and six resigned leaving a total membership of 209.

Eight meetings had been held during the session, four in the Society's room and four in the Physiological Lecture Theatre of the University. The average attendance had been fifty-five, an increase on that of the previous session, when the average attendance was forty-eight.

The second meeting of the session was held on Wednesday, 14th November, 1928, the President, Dr. H. L. Ormerod in the Chair.

Mr. E. Watson-WiLliams showed again the cases of carcinoma of the tonsil that he had brought before the Society in the previous session, to demonstrate the results of various methods of treatment. 